\title{
THE USE OF THE DATA BANK IN COMMUNE DEVELOPMENT PLANNING IN THE KUYAVIAN-POMERANIAN PROVINCE
}

\author{
Malgorzata Michalcewicz-Kaniowska ${ }^{1}$, Malgorzata Zajdel' Roman Rolbiecki ${ }^{2}$
}

1,2 UTP University of Science and Technology

\begin{abstract}
A very important task for local authorities is to properly plan and establish their long-term development policies. To this end, being informed on the possibilities of using official statistical data from the Local Data Bank (LDB) is necessary. These data constitute the basis for preparation of various analyses, trends, strategies, reports, and statements. The results of the study were obtained in order to find the answer to the research problem stated as follows: Are offices operating in rural areas informed on the LDB and on employing official statistical data for their own identified purposes? The subject of the study included local government units in the Kuyavian-Pomeranian province. The main aim of the study was to evaluate the extent of knowledge and the degree to which the Local Data Bank was used for the purposes of regional development. In order to achieve this aim, 157 Commune Offices within the area of the Kuyavian-Pomeranian province were surveyed. The surveys showed that the extent of knowledge regarding the Local Data Bank and its potential is very small, while general availability of the LDB is very limited.
\end{abstract}

Key words: Local Data Bank, official statistics, special, regional development, commune development strategy. JEL code: R58

\section{Introduction}

Significance of the addressed topics regarding official statistics and use of the Local Data Bank (LDB), particularly in local government units in rural areas, arises from the fact that the units are responsible for establishing proper social and economic development policy. The issues of official statistical data and its applications are becoming an important task to be dealt with by institutions responsible for regional development. In Poland, the official statistics information system is built by a number of institutions. The aim of these entities is to provide high quality comparable data for areas of various sizes in the long-term perspective. Thereby, statistical data on sustainable development are collected and published, e.g. by the Central Statistical Office (Bal-Domanska B., 2016).

Moreover, in conditions of globalisation, popularisation of statistical data methods (including access to information) and methods of statistical survey result analysis is growing important. Official statistics should be the basis of accurate diagnosis of the social and economic situation as well as an element of monitoring (Witkowski J., 2010). The recent years have seen a large increase in interest in statistical data, especially among districts and communes (Pieniazek M., 2015). As a consequence, the desire to make official statistics so useful in practice so that it could have an effect on long-term development and not just short-term consumption, e.g. consumption of EU funds, has been identified. The demand for statistical data on the local level is also increasing, which is caused by the growing importance of the use of statistical information in spatial planning involving methods in which Geographic Information Systems (GIS) are used, among other things (Parteka T., Czochanski J. T., 2005).

It is important to note that official statistics play a key role in the process of monitoring social and economic development. Provision of statistical information is becoming an indispensable element of management processes, the process of making effective decisions and undertaking actions as well as in planning and achieving strategic goals (Pieniazek M., Rogalinska D., 2017).

This paper presents selected results of the study concerning different aspects of using the available official statistics information resources for purposes including (but not limited to) strategic management in communes of the Kuyavian-Pomeranian Province. 
The subject of the study included local government units in the Kuyavian-Pomeranian province. The hypothesis of the research, assumes that the Local Data Bank is a valuable source of data to prepare the strategy. The main aim of the study was to evaluate the extent of knowledge and the degree to which the Local Data Bank was used for the purposes of regional development. The specific aim was to indicate areas in which the collected data (official statistical data) could be applied, to evaluate assets in view of needs of the communes as well as to evaluate the use of IT assets for the purposes of preparing strategic documents. An additional aim was to study opinions on the Local Data Bank platform itself with regard to such criteria as:

- content of the displayed data,

- clarity of the displayed data,

- coherence of the displayed data,

- the data sought being easy to find,

- using the portal,

- navigating the website,

- available tools.

In order to achieve this aim, 157 Commune Offices within the area of the Kuyavian-Pomeranian Province were surveyed.

\section{Research results and discussion}

The largest database for economy, society, and environment in Poland is the Local Data Bank (LDB). It contains over 40.000 statistical variables grouped by topics and covers the period since 1995. The LDB contains:

- data and indices describing statistical localities, communes, districts, provinces, and Poland as a whole as well as units accordant with the NTS (Nomenclature of Territorial Units for Statistical Purposes) naming convention: sub-regions and regions,

- information resources (annual and short-term statistical data) are completed and updated on a current basis,

- additional options - territory portraits (summaries), ratings, Statistical Handbook for Local Government Employees, sustainable development indices - are available in the Domain Databases - Multi-domain statistics (Bank Danych Lokalnych, 2018).

The Local Data Bank is a universal tool used to evaluate strategic sustainable development actions for the purposes of local, regional, or national planning. National census results and official statistics information resources, including administrative data, are the source of data constituting the Local Data Bank. It is the source of information used for interregional and time-based comparison (Marczak S; Pluto-Kossakowska J., 2014).

Statistical data should be used in strategic planning and current decision making processes. Analysis of the changes and phenomena that are taking place should be conducted by local government authorities using statistical information. As D. Wyszkowska states, local governments can use data prepared by the Polish official statistics service and based on research on the so-called short-term territorial statistics while making various decisions. These include information on the employment market, industry in general and the construction industry, agriculture, business entities, enterprise finance, investment outlays as well as condition and structure of the population. Furthermore, data on new phenomena and processes associated with the economic system 
transformation in Poland is also an important issue to be tackled by regional statistical services. (Portal samorzadowy; Wyszkowska D., 2017).

Official statistics index sets allow both evaluation of the current condition and determination of measurable goals. They are also applied in the process of monitoring changes that are taking place and in evaluation of effects after decisions are made or actions are undertaken. It has to be expressly emphasised that monitoring is one of the most important elements of implementing regional development policies (Bal-Domanska B., 2015).

The National Regional Development Strategy 2010-2020 adopted by the Council of Ministers in 2010 has provided the opportunity of making institutional and systemic changes on the national and local government levels. Two new institutions can be established in this respect in order to support implementation of the regional policy. These are the National Territorial Observatory on the national level and Regional Territorial Observatories on the regional level. The task of observatories established at the regional level will be to carry out strategic research and analyses using various statistics. They will be based on the currently created region information Banks that are collections of papers or links to data sources, reports, or analyses (Stelmach-Fita B., Brodowicz D. P., 2017).

Regional policies require the process of monitoring understood as 'the process of systematic collection and processing (analysis) of reliable data (both quantitative and qualitative) regarding implementation of projects, programmes, and development strategies'1 (Malik K., 2011).

Earlier study conducted by the present authors in 2013 covered the degree to which the Local Data Bank is used in respect of Commune Development Strategy planning. Its scope included all communes in the province. Its results showed that the Local Data Bank is popular only to a small extent and its impact on development strategy formation and planning is very low. Only $25 \%$ of the surveyed local administration units were making use of its capacities (Zajdel M., Michalcewicz-Kaniowska M., 2013).

The present study covered all local government units as well. The method of collecting data from primary sources was mail survey. Questionnaires accompanied by a cover letter were sent to each of the 157 Commune Offices in the Kuyavian-Pomeranian Province. The study was exhaustive in its nature, which means that it covered the entire subject population. Completed survey questionnaires were sent back by 94 offices, which is equal to nearly $60 \%$ of all communes covered by the study. Three counties ('starostwa'), 20 urban communes ('gminy miejskie'), 23 urban/rural communes ('gminy miejsko-wiejskie'), and 48 rural communes ('gminy wiejskie') participated in the study. Data analysis was conducted using descriptive statistics tools.

Communes are entirely free to develop strategic plans but at the same time they should make use of planning methods and techniques. Local development strategies constitute the territorial approach (Podejscie "Leader" podstawowy poradnik, 2006).

They are the ones that have to implement regional development policies such as those on education, health, social assistance, unemployment prevention, culture, land and water management, environment protection, communication, safety etc. (Wiatrak A. P., 1998).

The study concerned issues such as the use of the Local Data Bank (LDB) in view of commune development planning in the Kuyavian-Pomeranian province, in both quantitative and qualitative aspect. The first question in the questionnaire touched upon the LDB frequency of use. The answers given are shown in Figure 1.

1 Original quote in Polish: 'proces systematycznego gromadzenia i przetwarzania (analizowania) wiarygodnych danych (ilosciowych i jakosciowych) dotyczacych wdrazania projektow, programow i strategii rozwoju'. 


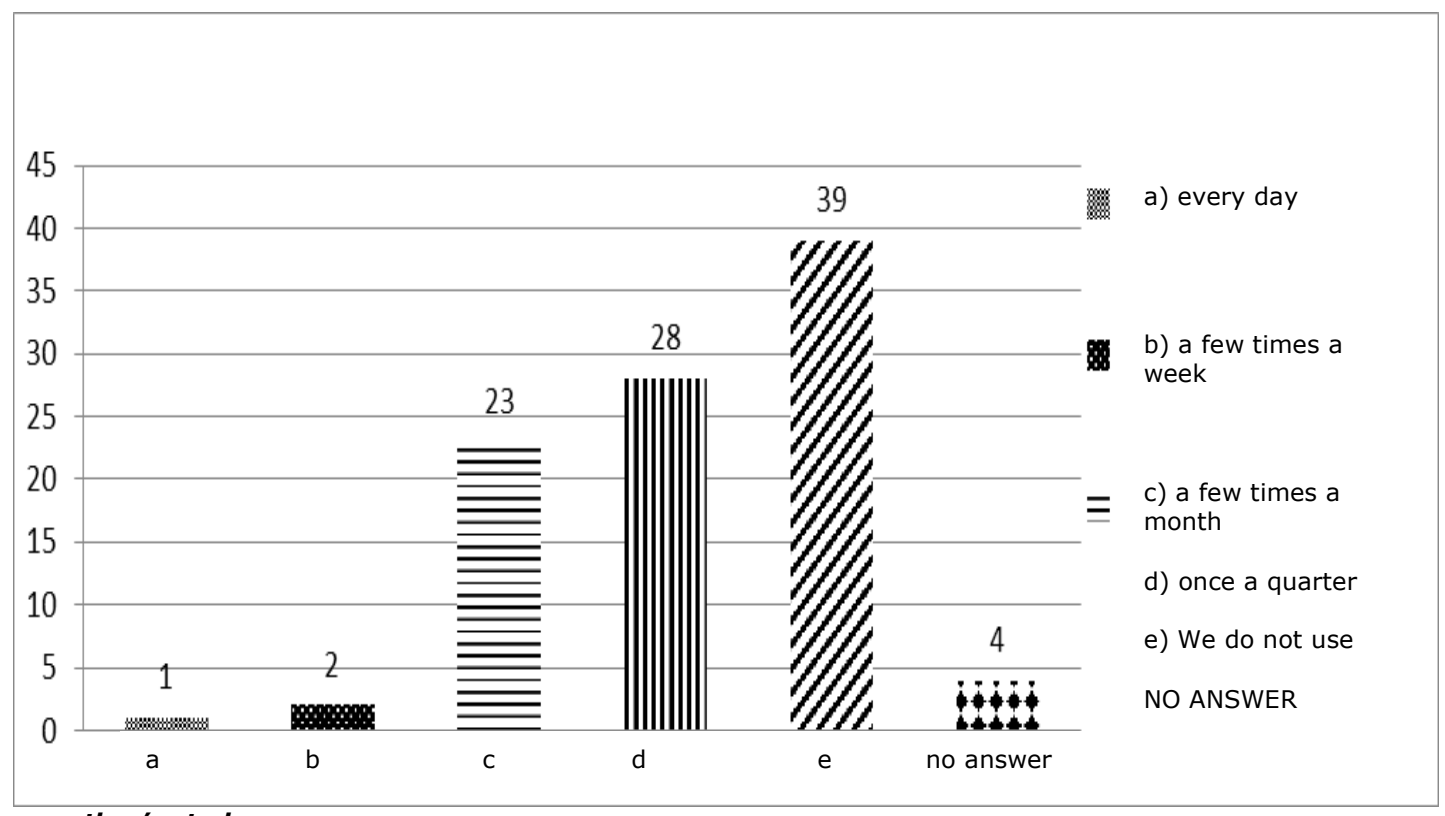

Source: author's study

Fig. 1. The LDB frequency of use

The survey demonstrated that over $40 \%$ of the analysed communes were not using the Local Data Bank and only $30 \%$ were using it once a quarter. The Bank was used on a daily basis or a few times a week by just $3 \%$ of the interviewees. A qualitative analysis showed that interviewees who used the LDB a few times a month had used the data, e.g. to:

- update and prepare development programmes,

- analyse demographic trends for strategic plans,

- provide current analyses needed for statistics, e.g. for operation of the Commune Office and Commune Council in order for them to be able to make decisions or adopt resolutions,

- prepare assessments and compare data covering a few years.

On the other hand, interviewees from communes who used the LDB once a quarter had used the data, e.g. to:

- update district statistical data to be used in articles, publications, EU projects,

- prepare various analyses, forecasts, long-term reports,

- describe the potential of a commune, promote it commercially,

- monitor and verify strategies,

- prepare assessments in strategic documents, development programmes and plans,

- obtain statistical information used for preparation of plans, strategies, and other documents that are strategic in nature,

- create a variety of informative materials and analyses needed in subsidy applications.

The next aspect of the study was concerned with analysing information needs of communes in view of LDB resources. Accordingly, $14 \%$ of the interviewees responded that data resources in the LDB satisfied their needs, $40 \%$ responded that these resources were not always sufficient, and more than $35 \%$ of the communes did not answer this question (Figure 2). 


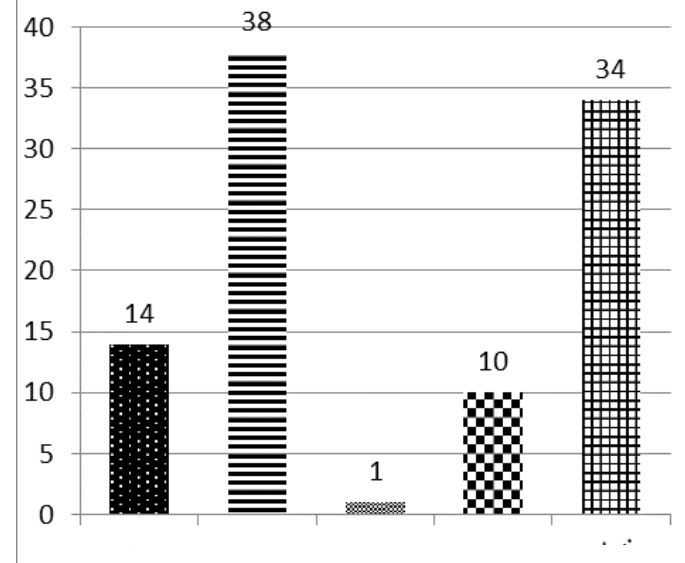

a) Yes

= b) Not always

c) No

n d) I do not know

\# e) NO ANSWER

\section{Source: author's study}

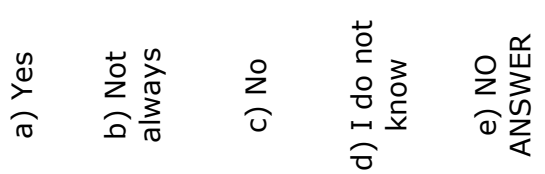

Fig. 2. Does the data available in the Local Data Bank sufficiently satisfy your needs?

The interviewees who responded that they were using the LDB and that the bank resources were sufficient had used the data to:

- update district statistical data to be used in articles, publications, EU projects,

- update and prepare development programmes,

- prepare assessments for strategic documents,

- draw up e.g. planning documents used to draft designs,

- describe the state of affairs in national and EU subsidy application forms.

The use of LDB resources in communes using the Bank that deemed the resources not always sufficient was also the subject of analysis. The interviewees' answers indicated that the data had been used, e.g. in:

- analyses, forecasts, reports, strategies,

- current analyses needed for statistics, e.g. for operation of the Commune Office and Commune Council in order for them to be able to make decisions or adopt resolutions,

- preparation of statements, surveys, strategic documents, feasibility studies for the implemented projects,

- statements, projects etc. where the commune needs to be characterised or similarly described.

- preparation of assessments in strategic documents, development programmes and plans, reports,

- to fill in surveys and statements as well as documentation.

The third issue covered in the questionnaire concerned the LDB as a source of information used in preparation of various strategic documents or studies. The survey revealed that, out of 97 communes that had sent the questionnaire back, 29 communes were using the LDB to prepare various analyses, 18 - to prepare forecasts, 20 - to prepare reports, 46 are using LDB resources to establish strategic plans, and only 28 communes were using the LDB to prepare other studies.

Another aspect of the study pertained to evaluation of the LDB by potential users in 7 areas:

- content of the displayed data, 
- clarity of the displayed data,

- coherence of the displayed data,

- the data sought being easy to find,

- using the portal,

- navigating the website,

- available tools.

As far as content of the displayed data is concerned, the results show that $41 \%$ of the communes rated this aspect 'very good' but more than $42 \%$ of the communes did not answer this question. Clarity of the displayed data was rated 'very good' and 'good' by more than $41 \%$ of the interviewees, while in $43 \%$ of the communes the question regarding this aspect was left with no answer. As for coherence of the displayed data, the evaluation was similar, i.e. more than $43 \%$ answered 'very good' or 'good', while $42 \%$ of the communes did not choose any answer at all. The next evaluated criterion was whether the data was easy to find; however, only $34 \%$ of the communes rated this aspect 'good' and 'very good', with $20 \%$ answering 'mediocre'. The aspects concerning use of the portal and navigation on the website were rated 'good' and 'very good' by $34 \%$ of the interviewees, whereas $22 \%$ rated it 'mediocre'. Availability of tools received similar ratings. This aspect was rated 'very good' and 'good' by $31 \%$ of the interviewees, 'mediocre' by $22 \%$ of the communes, and left with no answer by $43 \%$ of the subjects.

The last aspect of the study touched upon the possibility of using other databases. In this respect, $43 \%$ of the communes answered that they were not using any other portal, whereas $40 \%$ answered that they were. Qualitative analysis suggested the following sources:

- Commune Office databases,

- the Central Statistical Office,

- official gazettes,

- data from the Marshal's Office,

- the legal database - Lex,

- grants map,

- journals, data from books.

\section{Conclusions, proposals, recommendations}

1) Results of this study conducted on communes suggest that the extent of knowledge regarding the Local Data Bank itself as well as its potential is very small. This means that general availability of the LDB in the Kuyavian-Pomeranian province is still very limited. The Central Statistical Office should extend the scope of its educational activity.

2) The subjects indicated that data stored in the Local Data Bank are used predominantly to prepare current assessments and reports.

3) The period of validity for development strategies implemented by most of the communes is coming to an end. Therefore, the need for expertise in planning methods and techniques is growing. It can be significant during establishment of new strategies.

4) An apparent default on the part of communes covered by the study was that they still used the LDB and official statistical data from other sources to such a limited degree.

5) A very low percentage of communes have undertaken to prepare such plans. 


\section{Bibliography}

1. Bal-Domanska, B. (2015). Statystyczne bazy danych jako narzedzie monitoringu zrownowazonego rozwoju - wybrane aspekty teoretyczne (Statistical Databases As A Tool For Monitoring Sustainable Development Selected Theoretical Aspects) Przeglad Statystyczny R. LXII - Zeszyt 4/2015; s. 435 - 455

2. Bal-Domanska, B. (2016) Wybrane problemy budowy zestawow wskazników zrownowazonego rozwoju na poziomie lokalnym i regionalnym na przykładzie Banku Danych Lokalnych (Selected Problems Of Building Sets Of Indicators Of Sustainable Development On The Local And Regional Level On The Example Of The Local Data Bank); OPTIMUM. STUDIA EKONOMICZNE NR 1 (79) 2016 s. 150 - 164

3. Bank Danych Lokalnych (2018) (Local Data Bank); https://bdl.stat.gov.pl/BDL/start\#; dostep 2018

4. Malik, K. (2011) Ewaluacja polityki rozwoju regionu - metody, konteksty i wymiary rozwoju zrownowazonego (Evaluation Of Regional Development Policy - Methods, Contexts And Dimensions Of Sustainable Development), PAN KPZK, Warszawa,

5. Marczak, S., Pluto-Kossakowska, (2014); SPATIAL DATABASES TO ANALYZE THE USE OF EU FUNDS IN POLAND; Analizy wykorzystywania funduszy europejskich w Polsce (Analyzes Of The Use Of European Funds In Poland) Polskie Towarzystwo Informacji Przestrzennej, Roczniki Geomatyki 2014 m TOM XII m ZESZYT 1(63): 97;

6. Parteka, T., Czochanski, J.T. (2005); Monitorowanie programowania i zmian w przestrzeni jako instrument zarzadzania rozwojem regionalnym (Monitoring Programming And Changes In Space As An Instrument For Regional Development Management), w: Czyz T., Rogacki H. (red.), Wspolczesne problemy i koncepcje teoretyczne badan przestrzenno-ekonomicznych (Contemporary Problems And Theoretical Concepts Of Spatial And Economic Research), Biuletyn KPZK PAN, z. 219, Warszawa, s. 88-112.

7. Pieniazek, M,, Rogalinska, D. (2017) Rozwoj badan statystyki regionalnej na potrzeby monitorowania polityki spojnosci (Development Of Regional Statistics Surveys For Monitoring Cohesion Policy); w RESEARCH PAPERS OF WROCŁAW UNIVERSITY OF ECONOMICS nr 466,

8. Pieniazek, M., Rogalinska, D., (2015), Statystyka publiczna w procesie monitorowania wymiaru terytorialnego polityki spojnosci (Public Statistics In The Process Of Monitoring The Territorial Dimension of Cohesion Policy), [w] RESEARCH PAPERS OF WROCLAW UNIVERSITY OF ECONOMICS, t. 380, s. 158-165.

9. Podejscie "Leader": podstawowy poradnik (2006) (Leader Approach: A Basic Guide), Urzad Oficjalnych Publikacji Wspolnot Europejskich, Luksemburg, s. 8

10. Portal samorzadowy; Wyszkowska D; http://www.portalsamorzadowy.pl/prawo-i-finanse/jak-statystykamoze-wspierac-rozwoj-wojewodztw, 40567.html; dostep 2017

11. Stelmach-Fita, B., Brodowicz, D.P. (2017) Baza wiedzy o regionie i jej potencjalna oraz faktyczna rola w rozwoju terytorium (Knowledge Base About The Region And Its Potential And Actual Role In The Development Of The Territory); Biuletyn KPZK PAN, Zeszyt 267, s2]

12. Wiatrak, A.P. (1998) Przedsiebiorczosc w strategii rozwoju gminy w: Agrobiznes w krajach Europy Srodkowej w aspekcie integracji z Unia Europejska (Entrepreneurship In The Commune Development Strategy In: Agribusiness In The Countries Of Central Europe In The Aspect Of Integration With The European Union);V Kongres Stowarzyszenia Rolnictwa i Agrobiznesu, Wydawnictwo AE we Wroclawiu, Wroclaw, s.523

13. Witkowski, J. (2010). Wiadomosci Statystyczne (Statistical News); Nr 2 (585);

14. Zajdel, M., Michalcewicz-Kaniowska, M. (2013) Bank Danych Regionalnych w aspekcie planowania Strategii Rozwoju Gminy (Regional Data Bank In The Aspect Of Planning The Commune Development Strategy), Europa Regionum, Tom XVI, s. 191 - 199, 2013, 